\title{
Isolation and synthesis of falcitidin, a novel myxobacterial-derived acyltetrapeptide with activity against the malaria target falcipain-2
}

\author{
Brinda Somanadhan ${ }^{1}$, Santosh R Kotturi ${ }^{2}$, Chung Yan Leong1, Robert P Glover ${ }^{1,3}$, Yicun Huang ${ }^{1,4}$, \\ Horst Flotow $^{1,5}$, Antony D Buss ${ }^{1}$, Martin J Lear ${ }^{2,6}$ and Mark S Butler ${ }^{1,2,7}$
}

A 384-well microtitre plate fluorescence cleavage assay was developed to identify inhibitors of the cysteine protease falcipain-2, an important antimalarial drug target. Bioassay-guided isolation of a $\mathrm{MeOH}$ extract from a myxobacterium Chitinophaga sp. Y23 isolated from soil collected in Singapore, led to the identification of a new acyltetrapeptide, falcitidin (1), which displayed an IC $\mathrm{C}_{50}$ value of $6 \mu \mathrm{m}$ against falcipain-2. The planar structure of 1 was secured by NMR and MS/MS analysis. Attempts to isolate further material for biological testing were hampered by inconsistent production and by a low yield $\left(<100 \mu \mathrm{g} \mathrm{I}^{-1}\right)$. The absolute configuration of 1 was determined by Marfey's analysis and the structure was confirmed through total synthesis as isovaleric acidD-His-L-Ile-L-Val-L-Pro- $\mathrm{NH}_{2}$. Falcitidin (1) is the first member of a new class of falcipain-2 inhibitors and, unlike other peptidebased inhibitors, does not contain reactive groups that irreversibly bind to active cysteine sites.

The Journal of Antibiotics (2013) 66, 259-264; doi:10.1038/ja.2012.123; published online 23 January 2013

Keywords: Chitinophaga; falcipain; falcitidin; malaria; myxobacteria; tetrapeptide

\section{INTRODUCTION}

Malaria is a mosquito-borne disease caused by protozoa with Plasmodium falciparum, being the most lethal species to humans. According to WHO's 2011 World Malaria Report, 216 million cases of malaria were recorded during 2010, from which 665000 people died. ${ }^{1}$ The rapid life cycle of the malaria parasite has led to the emergence of drug resistant strains in a similar manner to other microorganisms. Currently artemisinin is considered the drug-of-last-resort but there are some recent reports that describe a growing number of resistant strains. $^{2-4}$ There is, therefore, still a need to identify new antimalarial drugs, especially those with new targets ${ }^{5}$ such as falcipain- $2,{ }^{6-8}$ a cysteine protease used by $P$. falciparum to help degrade hemoglobin during the trophozoite stage of infection. A recent review has comprehensively described the different classes of falcipain-2 inhibitors that include peptides, peptidomimetics, isoquinolines, thiosemicarbazones and chalcones. ${ }^{6}$

In our search for new antimalarial drug leads, a 384-well microtitre plate assay was developed using the falcipain-2 enzyme derived from the $P$. falciparum Gombak A strain. ${ }^{9}$ In this assay, protease activity was monitored by release of the fluorophore 4-amino-7-methyl coumarin (AMC) from the synthetic peptide substrate (Z-Phe-Arg$\mathrm{AMC}$ ). Compounds with inhibitory action would prevent the cleavage of the AMC fluorophore, thereby reducing the fluorescence intensity. Although only 2934 extracts were screened due to the limited availability of enzyme, an active $\mathrm{MeOH}$ extract was identified from a myxobacterium strain Y23 isolated from a soil sample collected in Singapore (Supplementary Figure S1). Sequencing of $16 \mathrm{~S}$ rDNA revealed that Y23 was a member of the genus Chitinophaga, which is a relatively new genus first described in $1981,{ }^{10,11}$ with a closest match to Chitinophaga terrae ( $94 \%$ sequence identity). ${ }^{12}$ Although usually found in soil, C. terrae has also been reported in an immunocompromised, human bacteremia patient. ${ }^{13}$ Chitinophaga has been previously reported to produce a series of unique methide antibiotics, the elansolids, ${ }^{14-16}$ and a plethora of volatile fatty acids and methyl esters. ${ }^{17}$

Bioassay-guided isolation led to the purification of a small amount $(0.5 \mathrm{mg})$ of a new acyltetrapeptide that was named falcitidin (1) and displayed an $\mathrm{IC}_{50}$ value of $6 \mu \mathrm{m}$ against the falcipain- 2 enzyme. The absolute configuration of 1 was determined using Marfey's method and the structure confirmed by total synthesis. Falcitidin (1) is the

\footnotetext{
${ }^{1}$ MerLion Pharmaceuticals, Singapore, Singapore and ${ }^{2}$ Department of Chemistry and Medicinal Chemistry Programme, National University of Singapore, Singapore, Singapore 3Present address: GSK Neural Pathways Discovery Performance Unit, 11 Biopolis Way, Helios Bldg \#03-01/02, Singapore 138667, Singapore.

${ }^{4}$ Present address: Chongqing Institute of Green and Intelligent Technology, Chinese Academy of Sciences, Blk B Hon Kwok Center No. 85, Jinyu Avenue, New North Zone, Chongqing 401122, P. R. China.

${ }^{5}$ Present address: Experimental Therapeutic Center (A*STAR), 31 Biopolis Drive, The Nanos \#02-29, Singapore 138669, Singapore.

6Present address: Department of Chemistry, Graduate School of Science, Tohoku University, Aoba-ku, Sendai 980-8578, Japan.

7Present address: Division of Chemistry and Structural Biology, Institute for Molecular Bioscience, University of Queensland, St Lucia 4072, QLD, Australia.

Correspondence: Dr MS Butler, Division of Chemistry and Structural Biology, Institute for Molecular Bioscience, University of Queensland, St Lucia, QLD, 4072, Australia.

E-mail: m.butler5@uq.edu.au
}

Received 6 June 2012; revised 17 December 2012; accepted 18 December 2012; published online 23 January 2013 
first representative of a new class of falcipain-2 inhibitors that in contrast to other peptide-based inhibitors does not contain reactive groups such as halomethyl ketones, vinyl sulfones, aldehydes, $\alpha$-ketoamides and aziridines, which covalently bind to the cysteine in the active site.

\section{RESULTS AND DISCUSSION}

\section{Physicochemical properties and structure elucidation} of falcitidin (1)

Falcitidin $(\mathbf{1})\left([\alpha]_{\mathrm{D}}^{31}-72(\mathrm{c} 0.28, \mathrm{MeOH})\right)$ was assigned a molecular formula of $\mathrm{C}_{27} \mathrm{H}_{45} \mathrm{~N}_{7} \mathrm{O}_{5}$ based upon HRMS data: ( -)-ESI-time of flight (TOF)-MS $m / z$ of $546.3402\left(\mathrm{C}_{27} \mathrm{H}_{44} \mathrm{~N}_{7} \mathrm{O}_{5}\right.$ requires 546.3404, 0.4 p.p.m.), and ( + )-ESI-TOF-MS $m / z 548.3553\left(\mathrm{C}_{27} \mathrm{H}_{46} \mathrm{~N}_{7} \mathrm{O}_{5}\right.$ requires 546.3560, 1.3 p.p.m. $)$ and $m / z 570.3379\left(\mathrm{C}_{27} \mathrm{H}_{45} \mathrm{~N}_{7} \mathrm{O}_{5} \mathrm{Na}\right.$ requires 570.3379, 0 p.p.m.) (Supplementary Figures S2 and S3). Analysis of the NMR data of falcitidin (1) in DMSO- $\mathrm{d}_{6}$ (Table 1, Supplementary Figure S4) suggested that 1 was a tetrapeptide, comprising of one unit of histidine, isoleucine, valine and proline, with an attached isovaleric acid (3-methylbutanoic acid) unit. It is interesting to note that isovaleric acid has been reported as one of the major volatile fatty acids in Chitinophaga sp. Fx7914. ${ }^{17}$ Although 2D NMR spectra could not unambiguously determine the position of the proline and valine units due to overlapping resonances, the planar structure of falcitidin (1) was secured using (+ )-ESI-MS/MS data obtained using an iontrap MS instrument. Analysis of the b-type MS/MS fragmentations ${ }^{18}$ (Figure 1) showed that the C-terminus was an amidated proline $(\mathrm{m} / \mathrm{z}$ 434.5 , isovaleric acid-Val-His-Ile-Val). The remaining fragments $(\mathrm{m} / \mathrm{z}$ 335.4 , isovaleric acid-His-Ile and $\mathrm{m} / \mathrm{z} 222.2$, isovaleric acid-His) were in accordance with the proposed structure of falcitidin (1) as the acylated tetrapeptide isovaleric acid-His-Ile-Val-Pro- $\mathrm{NH}_{2}$.

Due to the scarcity of natural material, the all $\mathrm{L}$ isomer of falcitidin (1b) was synthesized using standard peptide chemistry but was not identical to the natural product, as the ${ }^{1} \mathrm{H}$ NMR spectra were different (Figure 3 and Supplementary Figure S11) and co-injection of 1 and 1b using C18 HPLC resulted in two peaks (Figure 2b). The absolute configuration of $\mathbf{1}$ was then determined using Marfey's method. ${ }^{19,20}$ We used synthetic $\mathbf{1 b}$ to identify microwave-assisted hydrolysis ${ }^{21,22}$ as the optimal hydrolysis method, as conventional hydrolysis was not reproducible on sub-milligram amounts. The naturally occurring falcitidin (1) $(\sim 250 \mu \mathrm{g}$ in $0.2 \mathrm{ml}$ of aqueous $6 \mathrm{~N} \mathrm{HCl})$ was irradiated at $170{ }^{\circ} \mathrm{C}$ for $20 \mathrm{~min}$ and all of the individual amino acids of 1 (D-His, L-Ile, L-Val and L-Pro) were resolved by LC-MS after 1-fluoro-2-4dinitrophenyl-5-L-alanine amide-derivatization (Supplementary Figure S12). Therefore, the structure of falcitidin (1) was determined to be isovaleric acid-D-His-L-Ile-L-Val-L-Pro- $\mathrm{NH}_{2}$.

We next completed a total synthesis for structural correlation to natural 1 (Scheme 1, Supplementary Figures S5-S10). In short, after trifluoroacetic acid (TFA)-mediated removal of the Boc group of the $\mathrm{N}$-Boc-proline carboxamide 4, obtained from 3, the amino-proline TFA salt was coupled with freshly prepared L-Ile-L-Val 6 using $O$ (7-azabenzotriazol-1-yl)- $N, N, N^{\prime}, N^{\prime}$-tetramethyluronium hexafluorophosphate/1-hydroxy-7-azabenzotriazole (HATU/HOAt) to give L-IleL-Val-L-Pro- $\mathrm{NH}_{2} \quad 7 \mathbf{a}^{23}$ The dipeptide 6 was obtained by coupling L-Ile-NHBoc 2 with the in situ prepared bis-trimethylsilane (TMS) ether of L-Val (5) under mixed anhydride conditions. ${ }^{24}$ The Boc group of tripeptide $7 \mathbf{a}$ was then cleaved using TFA (via $7 \mathbf{b}$ ) and coupled to $N_{\alpha}$-Fmoc- $N_{(\mathrm{im})}$-trityl-D-histidine using HATU/HOAt to give the Fmoc-tetrapeptide $\mathbf{8}$. The Fmoc group of $\mathbf{8}$ was removed using piperidine $^{25}$ and isovaleric acid was attached to 9 using HATU/HOAt to give 10. The final synthetic target 1 was obtained after trityl deprotection of $\mathbf{1 0}$ using TFA in the presence of triisopropylsilane. ${ }^{26}$
Table 1 NMR data for falcitidin (1) (DMSO- $d_{6}, 500$ and $125 \mathrm{MHz}$ )

\begin{tabular}{|c|c|c|c|c|}
\hline Position & ${ }^{13} \mathrm{C} \delta$ & ${ }^{1} H \delta m, J(H z)$ & $\mathrm{COZY}$ & $g H M B C(H t$ \\
\hline \multicolumn{5}{|c|}{ Isovaleric acid } \\
\hline $1-\mathrm{CO}$ & $171.4^{\mathrm{a}}$ & - & - & - \\
\hline 2 & 44.2 & $1.95(\mathrm{~m})$ & Overlap & $3,4,5$ \\
\hline 3 & 24.9 & $1.92(\mathrm{~m})$ & Overlap & $2,4,5$ \\
\hline 4 & $21.9^{b}$ & $0.77(\mathrm{~d}, 6.3)^{\mathrm{b}}$ & 3 & $2,3,5$ \\
\hline 5 & $21.9^{b}$ & $0.80(\mathrm{~d}, 6.3)^{\mathrm{b}}$ & 3 & $2,3,4$ \\
\hline
\end{tabular}

$\begin{array}{lcccc}\begin{array}{l}\text { Histidine } \\ 2-\mathrm{CO}\end{array} & 171.1^{\mathrm{a}} & & & \\ \mathrm{NH} & - & 8.00(\mathrm{~d}, 8.2) & \alpha & \alpha, \beta, 1-\mathrm{CO} \\ \alpha-\mathrm{CH} & 52.7 & 4.55(\mathrm{~m}) & \beta, \mathrm{NH} & 2-\mathrm{CO} \\ \beta-\mathrm{CH}_{2} & 29.4 & 2.70(\mathrm{dd}, 5.7,14.8) & \mathrm{Ha}-\mathrm{Hb} & \alpha, \gamma, 2-\mathrm{CO} \\ & & 2.87(\mathrm{dd}, 8.8,14.8) & & \\ \gamma-\mathrm{C} & 132.1 \text { (weak) } & & & \\ \delta 2-\mathrm{CH} & 133.8^{\mathrm{a}} & 7.47(\mathrm{~s}) & \varepsilon 1 & \gamma \\ \varepsilon 1-\mathrm{CH} & \text { Not observed } & 6.79(\mathrm{~s}) & \delta 2 & - \\ \varepsilon 2-\mathrm{NH} & - & \text { Not observed } & - & \end{array}$

\begin{tabular}{|c|c|c|c|c|}
\hline \multicolumn{5}{|l|}{ Isoleucine } \\
\hline $3-\mathrm{CO}$ & $170.7^{a}$ & - & & - \\
\hline $\mathrm{NH}$ & - & $7.69(\mathrm{~d}, 9.1)$ & $\alpha$ & $2-\mathrm{CO}$ \\
\hline$\alpha-\mathrm{CH}$ & 56.4 & $4.21(m)^{d}$ & $\beta, \mathrm{NH}$ & $\beta, \gamma 1, \gamma 2,2-\mathrm{CO}$ \\
\hline$\beta-\mathrm{CH}$ & 36.5 & $1.64(\mathrm{~m})$ & $\gamma 1$ & \\
\hline$\gamma 1-\mathrm{CH}_{3}$ & 14.9 & $0.70(\mathrm{~d}, 7.2)$ & $\beta$ & $\alpha, \beta, \gamma 2$ \\
\hline$\gamma 2-\mathrm{CH}_{2}$ & 24.0 & $0.91(\mathrm{~m}), 1.25(\mathrm{~m})$ & $\mathrm{Ha}-\mathrm{Hb}, \beta, \delta$ & $\beta, \gamma 1, \gamma 2$ \\
\hline$\delta-\mathrm{CH}_{3}$ & 10.6 & $0.73(t, 7.2)$ & $\gamma 2$ & $\beta, \gamma 2$ \\
\hline \multicolumn{5}{|l|}{ Valine } \\
\hline 4-CO & $169.5^{a}$ & - & - & - \\
\hline $\mathrm{NH}$ & - & $7.96(d, 8.5)$ & $\alpha$ & $3-\mathrm{CO}$ \\
\hline$\alpha-\mathrm{CH}$ & 55.5 & $4.21(\mathrm{dd}, 8.5,8.5)^{\mathrm{d}}$ & $\beta, \mathrm{NH}$ & $\begin{array}{l}\beta, \gamma 1, \gamma 2 \\
3-\mathrm{CO}, 4-\mathrm{CO}\end{array}$ \\
\hline$\beta-\mathrm{CH}$ & 29.4 & $2.07(\mathrm{~m})$ & $\alpha, \gamma 1, \gamma 2$ & $\alpha, \gamma 1, \gamma 2$ \\
\hline$\gamma 1-\mathrm{CH}_{3}$ & $17.8^{c}$ & $0.86(d, 6.6)^{c}$ & $\beta$ & $\alpha, \beta, \gamma 2$ \\
\hline$\gamma 2-\mathrm{CH}_{3}$ & $18.5^{\mathrm{c}}$ & $0.88(d, 6.6)^{c}$ & $\beta$ & $\alpha, \beta, \gamma 1$ \\
\hline
\end{tabular}

$\begin{array}{ccccc}\begin{array}{c}\text { Proline } \\ 5-\mathrm{CO}\end{array} & 170.6^{\mathrm{a}} & - & - & - \\ \alpha-\mathrm{CH} & 59.1 & 4.21(\mathrm{~m})^{\mathrm{d}} & \beta & \beta, \gamma, 5-\mathrm{CO}^{\mathrm{d}} \\ \beta-\mathrm{CH}_{2} & 23.8 & 1.77(\mathrm{~m}), 1.91(\mathrm{~m}) & \mathrm{Ha}-\mathrm{Hb} & \gamma, \delta \\ \gamma-\mathrm{CH}_{2} & 28.8 & 1.77(\mathrm{~m}), 1.91(\mathrm{~m}) & \mathrm{Ha}-\mathrm{Hb} & \beta, \delta \\ \delta-\mathrm{CH}_{2} & 46.6 & 3.53(\mathrm{~m}), 3.74(\mathrm{~m}) & \beta, \gamma & \beta, \gamma \\ \mathrm{NH}_{2} & - & 6.74(\mathrm{~s}), 7.21(\mathrm{~s}) & - & \alpha\end{array}$

aThese resonances were not observed in the ${ }^{13} \mathrm{C}$ NMR spectrum and were obtained from gHMBC data.

${ }^{\mathrm{b} T}$ These assignments are interchangeable.

'These assignments are interchangeable.

'These isoleucine and valine proton resonances overlap and hence are indistinguishable by HMBC.

All characterization data and HPLC co-injection studies of synthetic 1 matched that of natural falcitidin (1) (Figures $2 \mathrm{c}$ and 3, Supplementary Figure S4).

\section{Biological properties of falcitidin (1)}

Falcitidin (1) displayed an $\mathrm{IC}_{50}$ of $6 \mu \mathrm{m}$ in the falcipain-2 assay. Counter screening of $\mathbf{1}$ against the aspartic protease plasmepsin-2, which is also a validated antimalarial target, gave an $\mathrm{IC}_{50}$ of $50 \mu \mathrm{m}$ in a fluorescence resonance energy transfer (FRET) assay and $65 \mu \mathrm{M}$ in a fluorescence polarization assay. ${ }^{27,28}$ Falcitidin (1) was inactive $\left(\mathrm{IC}_{50}>90 \mu \mathrm{M}\right)$ against the serine protease, tryptase. ${ }^{29}$ 


\section{CONCLUSION}

A new inhibitor of the antimalarial target falcipain-2 ( $\mathrm{IC}_{50} 6 \mu \mathrm{M}$ ), falcitidin (1), was isolated in small quantities from a myxobacterium Chitinophaga sp. collected from a soil sample in Singapore. The planar structure of 1 was secured by NMR and MS/MS analyses but attempts to isolate further material for biological testing were hampered by inconsistent production (even using identical fermentation conditions) and by a low yield (often $0 \mu \mathrm{g}^{-1}$ but never $>100 \mu \mathrm{g} \mathrm{l}^{-1}$ ). Therefore, falcitidin (1) needed to be synthesized to help confirm the structure. The synthesized all $\mathrm{L}$ isomer $\mathbf{1 b}$ was not identical to the natural product but was a useful tool to optimize the Marfey's amino analysis method. Microwave-assisted hydrolysis and 1-fluoro-2-4dinitrophenyl-5-L-alanine amide-derivatization established the structure of the naturally occurring peptide as isovaleric acid-DHis-L-Ile-L-Val-L-Pro- $\mathrm{NH}_{2}$, which was confirmed by total synthesis. A

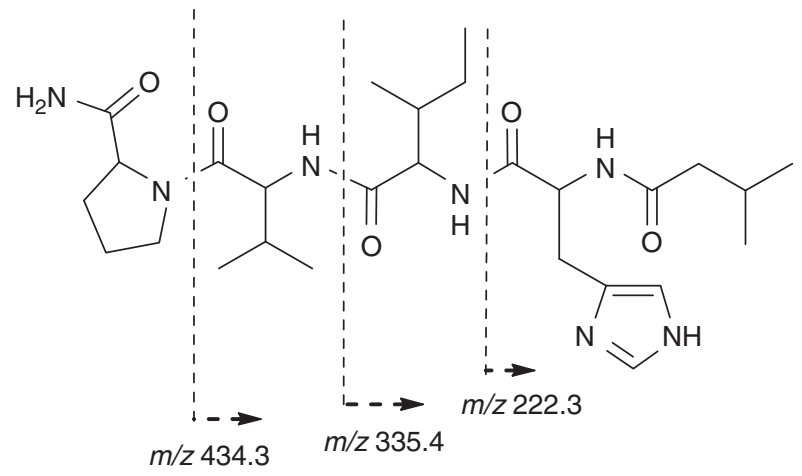

Figure 1 Planar structure of falcitidin (1) showing the b-type (+)-ESI-MS/ MS fragmentations used for structure elucidation.

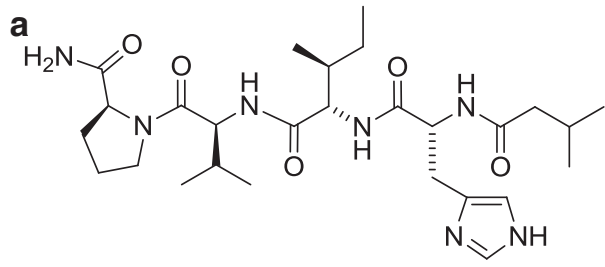

falcitidin (1)

isovaleric acid-D-His-L-Ile-L-Val-L-Pro- $\mathrm{NH}_{2}$

b $\mathrm{mAU}(\mathrm{x} 100)$

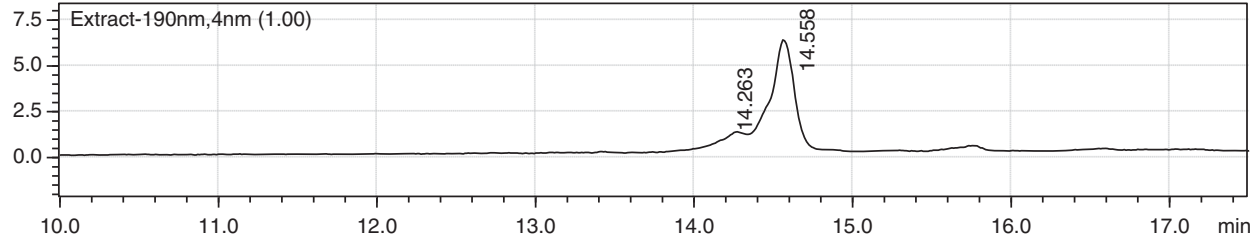

C $\operatorname{mAU}(x 100)$

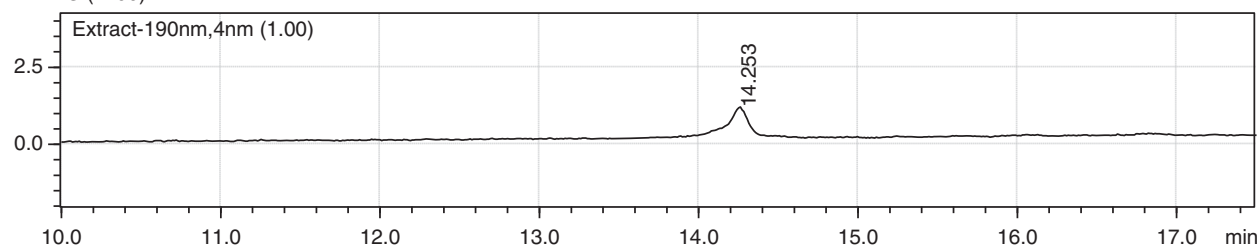

Figure 2 (a) Structures of falcitidin (isovaleric acid-D-His-L-Ile-L-Val-L-Pro- $\mathrm{NH}_{2}$ ) (1) and isovaleric acid-L-His-L-Ile-L-Val-L-Pro-NH 2 (1b). (b) HPLC chromatogram showing the retention times of natural falcitidin (1) $(14.3 \mathrm{~min})$ and synthetic $\mathbf{1 b}(14.6 \mathrm{~min})$ and; (c) co-elution of naturally occurring falcitidin (1) (14.3 min) and synthetic isovaleric acid-D-His-L-lle-L-Val-L-Pro- $\mathrm{NH}_{2}$ (1) (14.3 min). second generation total synthesis of $\mathbf{1}$ and in vitro antimalarial activity of falcitidin analogs will be reported in due course. Falcitidin (1) is the first member of a new class of falcipain-2 inhibitors and, unlike other peptide-based inhibitors, does not contain reactive groups that irreversibly bind to active cysteine sites.

\section{METHODS}

\section{General}

All reactions were performed under Ar atmosphere and stirred magnetically in oven-dried glassware, fitted with rubber septa. $\mathrm{CH}_{2} \mathrm{Cl}_{2}$ was dried by distilling over $\mathrm{CaH}_{2}$, whereas tetrahydrofuran (THF) was dried by distilling over sodium benzophenone ketyl. Inorganic salts and acids were used in aqueous solution and are reported in \% w/v. All reagents were obtained from Aldrich, Alfa Aesar, GL Biochem or TCI America (Singapore) and used without further purification unless otherwise stated. Vacuum liquid chromatography (VLC) was performed with Waters (Singapore) PREP C18 $(55-105 \mu \mathrm{m}$ particle size, $125 \AA$ ), whereas silica flash chromatography was performed using silica gel (25-40- $\mu \mathrm{m}$ particle size). TLC analyses were performed using pre-coated Merck Silica Gel 60 F254 glass slides and visualized with UV light or a ceric ammonium molybdate, $\mathrm{KMnO}_{4}$ and ninhydrin stain. $\mathrm{Rf}$ values were obtained by elution in the stated solvent ratios $(\mathrm{v} / \mathrm{v})$. All solvent mixtures are reported as $(\mathrm{v} / \mathrm{v})$ unless noted otherwise. Preparative HPLC was performed on a Waters system with Millenium ${ }^{32}$ software, Waters 996 PDA detector, Waters 600 gradient controller and pump, Waters 717plus autosampler and a Waters spectra were scanned on a Pharmacia Biotech Ultrospec 2000 (Pharmacia Biotech, Uppsala, Sweden). NMR spectra were collected on a Bruker Avance DRX-500 NMR spectrometer (Bruker, Bremen, Germany), using 5-mm broadband inverse (BBI) $\left({ }^{1} \mathrm{H}, \mathrm{G}-\mathrm{COZY}\right.$, multiplicity-edited gHSQC, and gHMBC) or broadband observe $(\mathrm{BBO})\left({ }^{13} \mathrm{C}\right.$ spectra) probe-heads equipped with z-gradients or a Bruker $300 \mathrm{MHz}$ spectrometer (Bruker) fitted with a pulse-field gradient probe. Samples were calibrated to the residual protonated solvent signals of DMSO- $d_{6}\left(\delta_{\mathrm{H}} 2.49\right.$ and $\left.\delta_{\mathrm{C}} 39.5\right)$ or TMS for CDCl $\mathrm{CDR}_{3}$. HR-ESIfraction collector II using a Luna C18(2) column $(5 \mu, 150 \times 21.2 \mathrm{~mm})$. UV

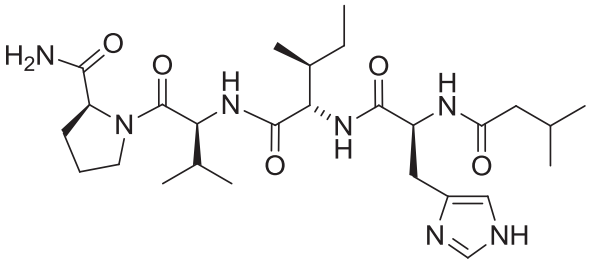

$1 \mathrm{~b}$

isovaleric acid-L-His-L-Ile-L-Val-L-Pro-- $\mathrm{NH}_{2}$ 


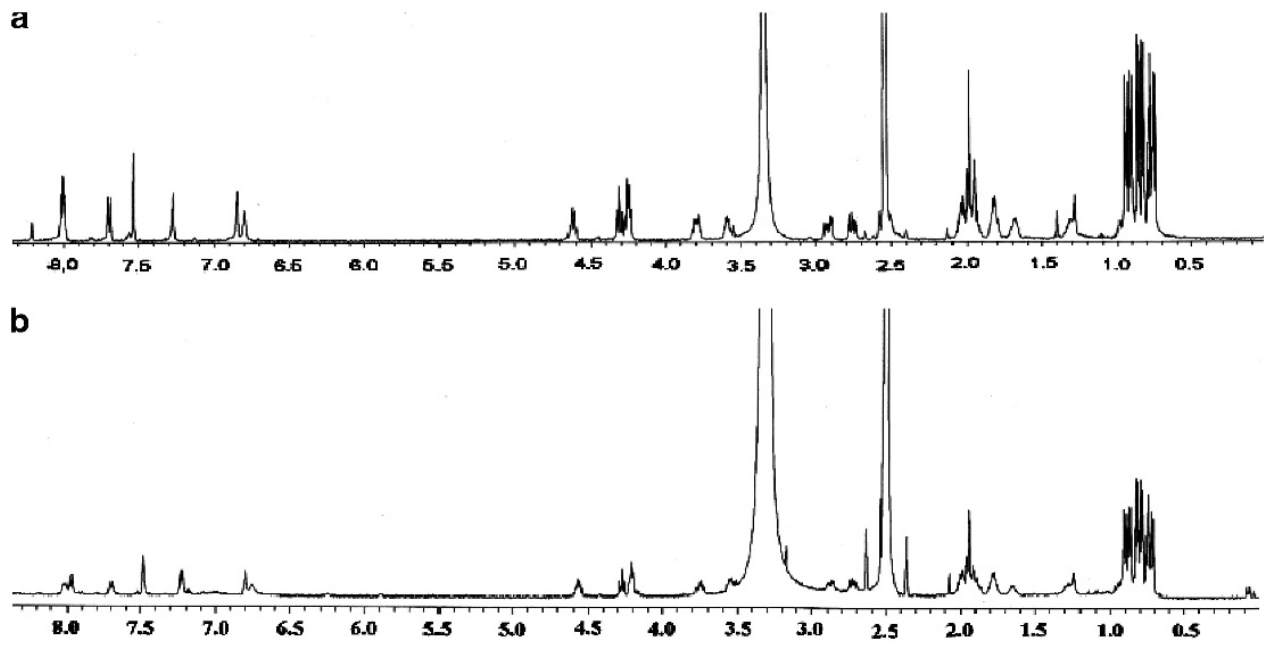

Figure $3{ }^{1} \mathrm{H}$ NMR (DMSO- $d_{6}$ ) correlation of (a) synthetic 1 with (b) natural falcitidin (1).
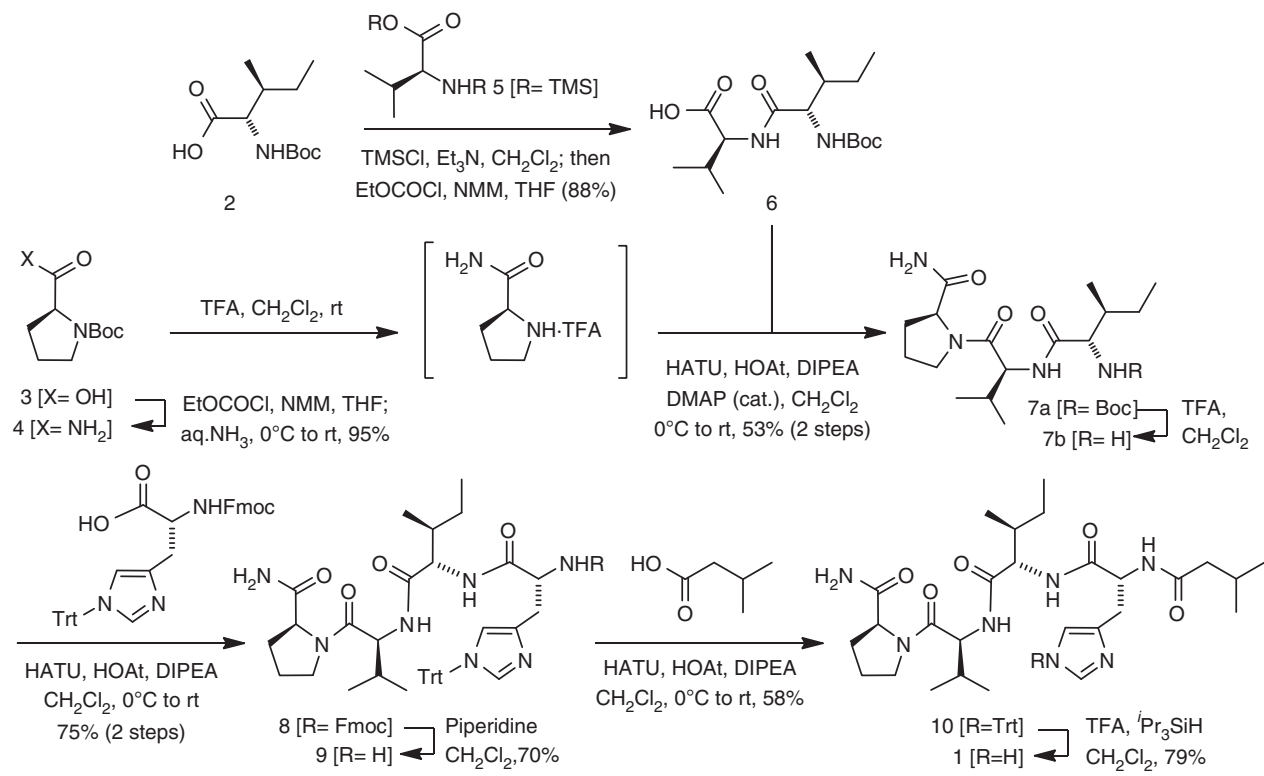

Scheme 1 Total synthesis of falcitidin (1) (isovaleric acid-D-His-L-lle-L-Val-L-Pro-NH $\mathrm{N}_{2}$ ).

MS values were collected on a Bruker microQTOF-Q mass spectrometer, using sodium formate as an internal standard for both positive- and negativeionization modes. MS/MS analysis was obtained on an ion-trap Bruker Esquire Mass Spectrometer (Bruker), which allows for the collection of ESI-MS/MS in alternating positive- and negative-ionization modes and is coupled with an Agilent 1100 Series HPLC (Agilent, Palo Alto, CA, USA). The MS analyses of synthetic compounds were recorded on a Finnigan LCQDECA (Thermo Finnigan, San Jose, CA, USA) or Thermo Finnigan MAT900XL mass spectrometer (Thermo Finnigan).

\section{Myxobacteria strain Y23 isolation and fermentation}

Strain Y23 was isolated from soil collected underneath a bamboo stand in Singapore. Sequencing of $16 \mathrm{~S}$ rDNA revealed strain Y23 to be a member of the genus Chitinophaga with a closest match ( $94 \%$ sequence identity) to C. terrae (accession number AB278570). ${ }^{12} \mathrm{Y} 23$ was subcultured for 7 days at $28^{\circ} \mathrm{C}$ on VY/2 agar, which consisted of Baker's yeast $5 \mathrm{~g}, \mathrm{CaCl}_{2} \bullet 2 \mathrm{H}_{2} \mathrm{O} 1.0 \mathrm{~g}$, agar $15 \mathrm{~g}$ in MilliQ water $11, \mathrm{pH}$ 7.2, which was autoclaved and then cyanocobalamin $500 \mu \mathrm{g}$ in $10 \mathrm{ml}$ of sterilized $\mathrm{H}_{2} \mathrm{O}$ was added. The actively growing subculture was used to inoculate 250-ml Erlenmeyer flasks that each contained $50 \mathrm{ml}$ of seed medium MD1. The MD1 medium was composed of Casitone $6 \mathrm{~g}$ (Difco, Detroit, MI, USA), $\mathrm{CaCl}_{2} \bullet 2 \mathrm{H}_{2} \mathrm{O} 0.7 \mathrm{~g}, \mathrm{MgSO}_{4} \bullet 7 \mathrm{H}_{2} \mathrm{O} 2 \mathrm{~g}$, cyanocobalamin $500 \mu \mathrm{g}$ in $10 \mathrm{ml}$ of sterilized $\mathrm{H}_{2} \mathrm{O}$ and trace elements $1 \mathrm{ml}$. The $\mathrm{pH}$ of the medium was not adjusted prior to being autoclaved at $121^{\circ} \mathrm{C}$ for $30 \mathrm{~min}$. The seed flasks were incubated for 2 days at $28^{\circ} \mathrm{C}$ on a rotary shaker with a $50 \mathrm{~mm}$ orbit at 200 r.p.m. A seed culture volume of $2.5 \mathrm{ml}$ was used to inoculate $50 \mathrm{ml}$ of the liquid medium in $250 \mathrm{ml}$ flasks containing $0.5 \mathrm{~g}$ of Sephabeads SP207 (Mitsubishi Chemical Corp., Tokyo, Japan). The liquid medium was composed of defatted soya flour $7.0 \mathrm{~g}$, Baker's yeast $3 \mathrm{~g}, \mathrm{CaCl}_{2} \bullet 2 \mathrm{H}_{2} \mathrm{O} 1.0 \mathrm{~g}$, $\mathrm{MgSO}_{4} \bullet 7 \mathrm{H}_{2} \mathrm{O} 1.0 \mathrm{~g}$, glucose $2 \mathrm{~g}$ and cyanocobalamin $0.1 \mathrm{mg}$ in 11 of MilliQ water. The $\mathrm{pH}$ was adjusted to 7.2 prior and the medium was autoclaved at $121^{\circ} \mathrm{C}$ for $30 \mathrm{~min}$. Fermentation was undertaken at 200 r.p.m. for 5 days at $28^{\circ} \mathrm{C}$.

\section{Extraction and isolation}

The broth from $20 \times 250 \mathrm{ml}$ flasks (total 5 liter) were mixed with Celite, homogenized for $30 \mathrm{~min}$, filtered under vacuum and the filtrate was separated 
by C18 VLC $(14.5 \times 10 \mathrm{~cm})$ eluted with $0,20,30,40,50$ and $100 \% \mathrm{MeOH}$ in $\mathrm{H}_{2} \mathrm{O}$ (2 liter each fraction). The $100 \% \mathrm{MeOH}$ fraction $(\sim 1 \mathrm{~g})$ was active in the falcipain-2 assay and was further separated by C18 VLC $(17 \times 4.5 \mathrm{~cm})$ using a $10 \%$ step-wise elution from $30 \%$ to $100 \% \mathrm{MeOH}$ in $\mathrm{H}_{2} \mathrm{O}$ (400 ml each fraction). Falcipain-2 activity was found in the $60 \%$ to $80 \% \mathrm{MeOH}$ in $\mathrm{H}_{2} \mathrm{O}$ fractions, which were combined $(80 \mathrm{mg})$ and separated using a Sephadex LH 20 column $(50 \times 2 \mathrm{~cm}$, eluent $\mathrm{MeOH})$. The active fraction $(8 \mathrm{mg})$ was separated by $\mathrm{C} 18$ preparative HPLC using the solvent $\mathrm{A}\left(0.1 \% \mathrm{HCO}_{2} \mathrm{H}\right.$ in $\left.\mathrm{H}_{2} \mathrm{O}\right)$ : solvent $\mathrm{B}$ (0.1\% $\mathrm{HCO}_{2} \mathrm{H}$ in $\mathrm{CH}_{3} \mathrm{CN}$ ), gradient elution from 100:0 to 95:5 for $2 \mathrm{~min}$ and then to $70: 30$ over $40 \mathrm{~min}$, flow rate $12 \mathrm{ml} \mathrm{min}^{-1}$ ) to obtain falcitidin (1) $(0.5 \mathrm{mg}$, retention time $20 \mathrm{~min})$. The biomass was fractionated in a similar manner as the broth, which yielded $\sim 0.5 \mathrm{mg}$ of peptide of $\sim 85 \%$ purity.

\section{Falcipain-2 biological assay}

An in vitro enzymatic assay was performed using a $15 \mu \mathrm{g} \mathrm{ml}^{-1}$ of the falcipain-2 derived from P. falciparum Gombak A strain ${ }^{9}$ to cleave $1 \mu \mathrm{M}$ substrate (Z-PheArg-AMC) peptide (Bachem AG, I1160) in a 384-well black microtitre plate (Griener, 781076) to identify potential inhibitors of falcipain-2. The buffer system contained $0.1 \mathrm{~m}$ sodium acetate buffer pH 5.6 (Merck, Singapore), $10 \mathrm{~mm}$ DTT (Boehringer Mannheim, 708992, Singapore), 0.1\% 3-[(3cholamidopropyl)dimethylammonio]-1-propanesulfonate (CHAPS) (Sigma, C3023, Singapore) and 20\% trehalose (Calbiochem, 625625, Singapore). After mixing the enzyme, substrate and test sample in buffer, the protease reaction was allowed to proceed at $4{ }^{\circ} \mathrm{C}$ overnight $(16 \mathrm{~h})$. The amount of released $\mathrm{AMC}$ was quantified by measuring its fluorescence using an Ultra (Tecan, Männedorf, Switzerland) with excitation at $360 \mathrm{~nm}$ and emission at $465 \mathrm{~nm}$. The percentage of (\%) enzyme inhibition was calculated using the following formula: ((Sample fluorescence -low fluorescence control)/(high fluorescence control-low fluorescence control) $) \times 100$. This assay had an overall signal to background ratio of $2.7 \pm 0.3$ and a $Z^{\prime}$ value of $0.66 \pm 0.13$, as no standard inhibitor was available when the assay was originally run.

\section{Plasmepsin-2 and tryptase biological assays}

The fluorescence resonance energy transfer and fluorescence polarization assay formats used for the plasmepsin-2 assays ${ }^{27,28}$ and the fluorescence quenching format used for the tryptase assay ${ }^{29}$ were performed as reported previously.

\section{General procedure for cleavage of $\mathrm{N}$-Boc group and amide coupling using HATU}

The Boc protected amino acid or peptide compound was dissolved in $\mathrm{CH}_{2} \mathrm{Cl}_{2}$, and TFA was added slowly at $0^{\circ} \mathrm{C}$ and the reaction was left stirring at room temperature for $30 \mathrm{~min}$. After completion of the reaction, excess TFA was removed using rotary evaporation and diethylether was added to precipitate the product. The supernatant diethylether layer was removed and the solid was dissolved in $\mathrm{CH}_{2} \mathrm{Cl}_{2}$. The $\alpha$-amino protected amino acid or peptide with free carboxy group was then added to the reaction flask at $0{ }^{\circ} \mathrm{C}$, followed by the addition of DIPEA, HATU and HOAt and a catalytic amount of DMAP. The reaction was stirred for $5 \mathrm{~h}$ at room temperature. After completion of the reaction, the reaction mixture was evaporated in vacuo and the residue dissolved in EtOAc. The organic layer was washed with saturated $\mathrm{NaHCO}_{3}$ solution, followed by brine solution. The organic layer was finally dried using $\mathrm{Na}_{2} \mathrm{SO}_{4}$ and evaporated in vacuo to give a solid residue that was purified by column chromatography.

\section{Preparation of dipeptide (6)}

(S)-2-((2S,3S)-2-(tert-butoxycarbonylamino)-3-methylpentanamido)-3-methyl butanoic acid: bis-TMS-valine (5) was separately prepared by dissolving L-valine $(1.6 \mathrm{~g}, 13.6 \mathrm{mmol})$ in $60 \mathrm{ml} \mathrm{CH} \mathrm{Cl}_{2}$. Triethyl amine $(6.7 \mathrm{ml}, 48 \mathrm{mmol})$ and trimethylsilylchloride $(6.1 \mathrm{ml}, 48 \mathrm{mmol})$ were then added $(2.0 \mathrm{~g}$, $8.65 \mathrm{mmol})$. The mixture was refluxed for $2 \mathrm{~h}$. The mixture was then used in situ for coupling to the anhydride. Thus, Boc-L-Isoleucine $2(2.0 \mathrm{~g}$, $8.65 \mathrm{mmol}, 1 \mathrm{eq}$ ) was dissolved in THF and the solution was maintained at $-20^{\circ} \mathrm{C}$ using an ice-salt bath. Then, $N$-methyl morpholine $(1.2 \mathrm{ml}, 10.3 \mathrm{mmol}$, $1.2 \mathrm{eq})$ was added followed by the addition of ethyl chlorofomate $(1.0 \mathrm{ml}$, $10.3 \mathrm{mmol}, 1.0 \mathrm{eq}$ ). The mixture was stirred at $-20^{\circ} \mathrm{C}$ for 15 to $20 \mathrm{~min}$. At this point, bis-TMS-valine (5) was added to the anhydride solution and stirred for
$10 \mathrm{~h}$ at room temperature. After that, the reaction mixture was concentrated by rotary evaporation. The residue obtained was dissolved in saturated $\mathrm{NaHCO}_{3}$ and the aqueous layer was washed with $n$-hexane. The aqueous bicarbonate layer was acidified with citric acid and then extracted with EtOAc. The organic layer was washed with brine, dried using anhydrous $\mathrm{Na}_{2} \mathrm{SO}_{4}$ and removed by rotary evaporation to give white solid, which was purified by silica column chromatography (hexane/EtOAc, 2.5:1) to give $6(2.5 \mathrm{~g}, 7.5 \mathrm{mmol}, 88 \%)$ as a white crystalline solid. ${ }^{1} \mathrm{H}$ NMR $\left(300 \mathrm{MHz}, \mathrm{DMSO}-\mathrm{d}_{6}\right) \delta 0.77-0.83(\mathrm{~m}, 6 \mathrm{H})$, $0.87(\mathrm{~m}, 6 \mathrm{H}), 1.08(\mathrm{~m}, 1 \mathrm{H}), 1.37(\mathrm{~s}, 9 \mathrm{H}), 1.58(\mathrm{~m}, 1 \mathrm{H}), 1.98(\mathrm{~m}, 2 \mathrm{H}), 3.84$ $(t, \mathrm{~J}=8.2 \mathrm{~Hz}, 1 \mathrm{H}), 4.13(\mathrm{dd}, \mathrm{J}=5.7,8.4 \mathrm{~Hz}, 1 \mathrm{H}), 6.73(\mathrm{~d}, \mathrm{~J}=9.0 \mathrm{~Hz}, 1 \mathrm{H}), 7.74$ $(\mathrm{d}, \mathrm{J}=8.4 \mathrm{~Hz}, 1 \mathrm{H}), 12.56(\mathrm{~s}, 1 \mathrm{H}) ;{ }^{13} \mathrm{C}$ NMR $\left(75 \mathrm{MHz}, \mathrm{DMSO}-\mathrm{d}_{6}\right) \delta 10.8,15.3$, 17.9, 18.9, 24.3, 28.1, 29.9, 36.3, 56.9, 58.7, 77.9, 155.8, 171.6, 172.7; ESI-MS $m / z$ $330.9(\mathrm{M}+\mathrm{H})^{+}, 353.1(\mathrm{M}+\mathrm{Na})^{+}$.

\section{Preparation of tripeptide (7a)}

Tert-butyl (2S,3S)-1-((S)-1-((S)-2-carbamoylpyrrolidin-1-yl)-3-methyl-1-oxobutan-2-ylamino)-3-methyl-1-oxopentan-2-ylcarbamate: Boc-L-proline amide $4(350 \mathrm{mg}, 1.6 \mathrm{mmol})$ was coupled to the dipeptide $6(647 \mathrm{mg}, 1.95 \mathrm{mmol})$ according to the general procedure for peptide coupling using HATU/HOAt to give the desired compound $7 \mathrm{a}(368 \mathrm{mg}, 0.86 \mathrm{mmol}, 53 \%)$ after silica column purification with $\mathrm{CHCl}_{3} / \mathrm{MeOH}(25: 1) .{ }^{1} \mathrm{H}$ NMR $\left(500 \mathrm{MHz}\right.$, DMSO-d $\left.\mathrm{d}_{6}\right) \delta 0.77$ $(\mathrm{m}, 6 \mathrm{H}), 0.85(\mathrm{~m}, 6 \mathrm{H}), 1.04(\mathrm{~m}, 1 \mathrm{H}), 1.37(\mathrm{~s}, 9 \mathrm{H}), 1.65(\mathrm{~m}, 1 \mathrm{H}), 1.75(\mathrm{~m}, 2 \mathrm{H})$, $1.82(\mathrm{~m}, 4 \mathrm{H}), 3.54(\mathrm{~m}, 1 \mathrm{H}), 3.70(\mathrm{~m}, 1 \mathrm{H}), 3.81(\mathrm{t}, 1 \mathrm{H}), 4.20(1 \mathrm{H}, \mathrm{m}), 4.33$ $(\mathrm{t}, 1 \mathrm{H}) 6.82(\mathrm{brs}, 2 \mathrm{H}), 7.24(\mathrm{~s}, 1 \mathrm{H}), 7.72(\mathrm{~d}, \mathrm{~J}=8.8 \mathrm{~Hz}, 1 \mathrm{H}) ;{ }^{13} \mathrm{C}$ NMR $(125$ MHz, DMSO-d $\left.{ }_{6}\right) \delta 10.8,15.3,18.1,19.1,24.4,28.1,29.2,30.1,36.5,46.9,58.8$, 78.0, 79.1, 155.2, 169.6, 171.2, 173.3; ESI-MS $m / z 427.0(\mathrm{M}+\mathrm{H})^{+}, 449.2$ $(\mathrm{M}+\mathrm{Na})^{+}$

\section{Preparation of Fmoc-tetrapeptide (8)}

(9H-fluoren-9-yl)methyl $(R)-1-((2 S, 3 S)-1-((S)-1-((S)$-2-carbamoylpyrrolidin-1yl)-3-methyl-1-oxobutan-2-ylamino)-3-methyl-1-oxopentan-2-ylamino)-1-oxo3-(1-trityl-1H-imidazol-4-yl)propan-2-ylcarbamate (8): Tripeptide 7 (160 mg, $0.37 \mathrm{mmol})$ was coupled to $N_{\alpha}$-fmoc- $N_{(\mathrm{im})}$-trityl-D-histidine $(256 \mathrm{mg}$, $0.41 \mathrm{mmol}$ ) using the general procedure for HATU coupling. The desired compound tetrapeptide $8(262 \mathrm{mg}, 0.28 \mathrm{mmol}, 75 \%)$ was obtained after silica column purification using chloroform/methanol $(25: 1) .{ }^{1} \mathrm{H}$ NMR $(300 \mathrm{MHz}$, $\left.\mathrm{CDCl}_{3}\right) \delta 0.75(\mathrm{~m}, 12 \mathrm{H}), 1.02(\mathrm{~m}, 1 \mathrm{H}), 1.18(\mathrm{~m}, 1 \mathrm{H}), 1.41(\mathrm{~m}, 1 \mathrm{H}), 1.87(6 \mathrm{H}$, $\mathrm{m}), 3.0(\mathrm{~d}, \mathrm{~J}=6.2 \mathrm{~Hz}, 2 \mathrm{H}), 3.61(\mathrm{~m}, 1 \mathrm{H}), 3.77(\mathrm{~m}, 1 \mathrm{H}), 4.19(\mathrm{~m}, 3 \mathrm{H}), 4.51(\mathrm{~m}$, $3 \mathrm{H}), 6.54$ (brs, $1 \mathrm{H}), 6.66(\mathrm{~s}, 1 \mathrm{H}), 7.06(\mathrm{~m}, 7 \mathrm{H}), 7.14$ (brs, $1 \mathrm{H}), 7.28(\mathrm{~m}, 14 \mathrm{H})$, 7.56 (m, 2H), 7.64 (brd, 1H), 7.72 (m, 2H), 7.79 p.p.m. (brd, $1 \mathrm{H}) ;{ }^{13} \mathrm{C}$ NMR $\left(75 \mathrm{MHz}, \mathrm{CDCl}_{3}\right) 11.3,15.8,17.9,19.2,24.4,25.0,27.7,31.2,47.0,47.7,55.1$, $55.8,57.8,59.3,67.2,75.3,119.3,119.8,125.1,125.2,127.0,127.6,128.0,129.6$, $138.5,141.1,141.2,142.2,143.7,143.9,171.2,171.3,171.7,173.5$; ESI-MS m/z $928.2(\mathrm{M}+\mathrm{H})^{+}, 950.4(\mathrm{M}+\mathrm{Na})^{+}$.

\section{Preparation of tetrapeptide (9)}

(S)-1- $((S)-2-((2 S, 3 S)-2-((R)-2$-amino-3-(1-trityl-1H-imidazol-4-yl)propanamido)-3-methylpentanamido)-3-methylbutanoyl)pyrrolidine-2-carboxamide (9): Fmoc-tetrapeptide 8 ( $140 \mathrm{mg}, 0.15 \mathrm{mmol})$ was cleaved using piperidine to give the desired compound $9(77 \mathrm{mg}, 0.11 \mathrm{mmol}, 70 \%) .{ }^{1} \mathrm{H}$ $\operatorname{NMR}\left(300 \mathrm{MHz}, \mathrm{CDCl}_{3}\right) \delta 0.83(\mathrm{~m}, 12 \mathrm{H}), 1.10(\mathrm{~m}, 1 \mathrm{H}), 1.40(\mathrm{~m}, 1 \mathrm{H}), 1.93$ $(\mathrm{m}, 6 \mathrm{H}), 2.82(\mathrm{~m}, 2 \mathrm{H}), 3.62(\mathrm{~m}, 1 \mathrm{H}), 3.85(\mathrm{~m}, 1 \mathrm{H}), 4.00(\mathrm{~m}, 1 \mathrm{H}), 4.30(\mathrm{~m}$, $1 \mathrm{H}), 4.53(\mathrm{~m}, 2 \mathrm{H}), 5.86(\mathrm{~s}, 1 \mathrm{H}), 6.63(\mathrm{~s}, 1 \mathrm{H}), 7.03$ (brs, $1 \mathrm{H}), 7.10(\mathrm{~m}, 6 \mathrm{H}), 7.16$ $(\mathrm{d}, 1 \mathrm{H}), 7.33(\mathrm{~m}, 9 \mathrm{H}), 7.46(\mathrm{~s}, 1 \mathrm{H}), 7.65(\mathrm{~d}, \mathrm{~J}=8.2 \mathrm{~Hz}, 1 \mathrm{H}), 8.28(\mathrm{~d}, \mathrm{~J}=8.2$ $\mathrm{Hz}, 1 \mathrm{H}) ;{ }^{13} \mathrm{C}$ NMR $\left(75 \mathrm{MHz}, \mathrm{CDCl}_{3}\right) \delta 11.2,15.7,18.1,19.1,24.6,24.9,28.2$, $30.6,32.2,36.5,47.6,54.5,55.9,58.4,59.5,75.1,119.5,127.9,129.5,136.7$, 138.6, 142.0, 171.3, 171.5, 173.4, 173.7; ESI-MS $m / z 706.1(\mathrm{M}+\mathrm{H})^{+}, 728.3$ $(\mathrm{M}+\mathrm{Na})^{+}$.

\section{Preparation of Trt-falcitidin (10)}

(S)-1-((S)-3-methyl-2-((2S,3S)-3-methyl-2-((R)-2-(3-methylbutanamido)3-(1-trityl-1H-imidazol-4-yl)propanamido)pentanamido)butanoyl)pyrrolidine2-carboxamide (10): Tetrapeptide 9 (74 $\mathrm{mg}, 0.1 \mathrm{mmol})$ was coupled to isovaleric acid $(10 \mu \mathrm{l}, 0.1 \mathrm{mmol})$ using the general procedure for HATU coupling. The desired compound $10(48 \mathrm{mg}, 0.06 \mathrm{mmol}, 58 \%)$ was obtained after silica column purification using chloroform/methanol (25:1). ${ }^{1} \mathrm{H}$ NMR 
$\left(500 \mathrm{MHz}, \mathrm{CDCl}_{3}\right) \delta 0.82(\mathrm{~m}, 18 \mathrm{H}), 1.05(\mathrm{~m}, 1 \mathrm{H}), 1.41(\mathrm{~m}, 1 \mathrm{H}), 1.92(\mathrm{~m}, 2 \mathrm{H})$, $2.02(\mathrm{~m}, 6 \mathrm{H}), 2.29(\mathrm{~m}, 1 \mathrm{H}), 2.92(\mathrm{~m}, 1 \mathrm{H}), 3.02(\mathrm{~m}, 1 \mathrm{H}), 3.57(1 \mathrm{H}, \mathrm{m}), 3.75$ $(1 \mathrm{H}, \mathrm{m}), 4.36(\mathrm{~m}, 1 \mathrm{H}), 4.53(\mathrm{~m}, 2 \mathrm{H}), 4.64(\mathrm{q}, \mathrm{J}=6.3 \mathrm{~Hz}, 1 \mathrm{H}), 6.67(\mathrm{~s}, 1 \mathrm{H})$ 6.94 (brs, 1H), 7.02 (brs, $1 \mathrm{H}), 7.08(6 \mathrm{H}, \mathrm{m}), 7.32(\mathrm{~m}, 11 \mathrm{H}), 7.98$ (brs, $1 \mathrm{H}) ;{ }^{13} \mathrm{C}$ NMR $\left(125 \mathrm{MHz}, \mathrm{CDCl}_{3}\right) \delta 11.4,15.8,17.9,19.3,22.4,22.5,24.6,25.0,26.0$, 27.1, 29.6, 29.7, 31.2, 36.8, 45.8, 47.7, 53.2, 55.7, 58.3, 59.3, 75.5, 119.4, 128.1, $129.7,138.1,142.1,171.1,171.6,171.7,173.1,173.2$; ESI-MS m/z 790.16 $(\mathrm{M}+\mathrm{H})^{+}$

\section{Preparation of synthetic falcitidin (1)}

$(S)-1-((S)-2-((2 S, 3 S)-2-((R)-3-(1 \mathrm{H}-$ imidazol-4-yl)-2-(3-methylbutanamido)propanamido)-3-methylpentanamido)-3-methylbutanoyl)pyrrolidine-2-carboxamide: Compound $10(57 \mathrm{mg}, 71 \mu \mathrm{mol})$ was dissolved in $\mathrm{CH}_{2} \mathrm{Cl}_{2}$ and then TFA was added followed by triisopropylsilane. After $1 \mathrm{~h}$, the reaction was complete. The solvent was removed in vacuo, saturated $\mathrm{NaHCO}_{3}$ added, and the aqueous layer was extracted with EtOAc. The EtOAc was removed by rotary evaporation and the residue was purified by preparative HPLC using the same conditions as the natural products to give $\mathbf{1}$ as the formate salt $(31 \mathrm{mg}$, $0.057 \mathrm{mmol}, 79 \%) .[\alpha]_{\mathrm{D}}{ }^{31}-67$ (c $\left.0.84, \mathrm{MeOH}\right)\left[\mathbf{1}:[\alpha]_{\mathrm{D}}{ }^{31}-72\right.$ (c 0.28 , $\mathrm{MeOH}$ )]; HPLC co-elution with naturally occurring peptide (Figure $2 \mathrm{c}$ ); ${ }^{1} \mathrm{H}$ NMR identical to natural product (Figure 3).

\section{ACKNOWLEDGEMENTS}

We thank the National University of Singapore for a Graduate Scholarship (to SRK) and generous funding from the National Medical Research Council (NMRC/IRG11may097) of Singapore (to MJL).

1 WHO. World Malaria Report $2011<\mathrm{http} / /$ www.who.int/malaria/world malaria report $2011>$ (accessed 13 December 2012).

2 Plowe, C. et al. World Antimalarial Resistance Network (WARN) III: Molecular markers for drug resistant malaria. Malar. J. 6, 121 (2007).

3 Thomsen, T. T. et al. Prevalence of single nucleotide polymorphisms in the Plasmodium falciparum multidrug resistance gene (Pfmdr-1) in Korogwe District in Tanzania before and after introduction of artemisinin-based combination therapy. Am. J. Trop. Med. Hyg. 85, 979-983 (2011).

4 Petersen, I., Eastman, R. \& Lanzer, M. Drug-resistant malaria: Molecular mechanisms and implications for public health. FEBS Lett. 585, 1551-1562 (2011).

5 Burrows, J. N., Leroy, D., Lotharius, J. \& Waterson, D. Challenges in antimalarial drug discovery. Future Med. Chem. 3, 1401-1412 (2011).

6 Ettari, R., Bova, F., Zappalà, M., Grasso, S. \& Micale, N. Falcipain-2 inhibitors. Med. Res. Rev. 30, 136-167 (2010).

7 Pandey, K. Cysteine proteases of human malaria parasites. J. Parasit. Dis. 35, 94-103 (2011).

8 Rosenthal, P. J. in Advances in Experimental Medicine and Biology Vol. 712 (eds Robinson, M. W. \& Dalton, J. P.) 30-48 (Springer, New York, 2011).
9 Sim, T.-S., Loke, P., Lee, M., Singh, M. \& Flotow, H. Cloning and sequence characterisation of falcipain-2 from Plasmodium falciparum Gombak A strain (Malaysia). Parasitol. Res. 87, 683-686 (2001).

10 Kämpfer, P. et al. Transfer of [Flexibacter] sancti, [Flexibacter] filiformis, [Flexibacter] japonensis and [Cytophaga] arvensicola to the genus Chitinophaga and description of Chitinophaga skermanii sp. nov. Int. J. Syst. Evol. Microbiol. 56, 2223-2228 (2006)

11 Sangkhobol, V. \& Skerman, V. B. D. Chitinophaga, a new genus of chitinolytic myxobacteria. Int. J. Syst. Bacteriol. 31, 285-293 (1981).

12 An, D. S., Im, W. T., Lee, S. T., Choi, W. Y. \& Yoon, M. H. Chitinophaga soli sp. nov. and Chitinophaga terrae sp. nov., isolated from soil of a ginseng field in Pocheon Province, Korea. J. Microbiol. Biotechnol. 17, 705-711 (2007).

13 Cremet, L. et al. Chitinophaga terrae bacteremia in human. Emerg. Infect. Dis. 15, 1134-1135 (2009)

14 Dehn, R. et al. Molecular basis of elansolid biosynthesis: Evidence for an unprecedented quinone methide initiated intramolecular Diels-Alder cycloaddition/macrolactonization. Angew. Chem. Int. Ed. 50, 3882-3887 (2011).

15 Jansen, R. et al. Elansolid A3, a unique p-quinone methide antibiotic from Chitinophaga sancti. Chemistry 17, 7739-7744 (2011).

16 Steinmetz, $H$. et al. Elansolid A, a unique macrolide antibiotic from Chitinophaga sanct isolated as two stable atropisomers. Angew. Chem. Int. Ed. 50, 532-536 (2011).

17 Nawrath, T., Gerth, K., Müller, R. \& Schulz, S. Volatile methyl esters of medium chain length from the bacterium Chitinophaga Fx7914. Chem. Biodiversity 7, 2228-2253 (2010)

18 Johnson, R. S., Martin, S. A., Biemann, K., Stults, J. T. \& Watson, J. T. Novel fragmentation process of peptides by collision-induced decomposition in a tandem mass spectrometer: differentiation of leucine and isoleucine. Anal. Chem. 59, 2621-2625 (1987)

19 Marfey, P. Determination of D-amino acids. II. Use of a bifunctional reagent, 1,5difluoro-2,4-dinitrobenzene. Carlsberg Res. Commun. 49, 591-596 (1984).

20 Bhushan, R. \& Brückner, H. Use of Marfey's reagent and analogs for chiral amino acid analysis: Assessment and applications to natural products and biological systems. J. Chromatogr. B 879, 3148-3161 (2011).

21 Chiou, S.-H. \& Wang, K.-T. Peptide and protein hydrolysis by microwave irradiation. J. Chromatogr. B 491, 424-431 (1989).

22 Lill, J. R., Ingle, E. S., Liu, P. S., Pham, V. \& Sandoval, W. N. Microwave-assisted proteomics. Mass Spectrom. Rev. 26, 657-671 (2007).

23 Carpino, L. A., Ionescu, D. \& El-Faham, A. Peptide coupling in the presence of highly hindered tertiary amines. J. Org. Chem. 61, 2460-2465 (1996).

24 Bambino, F., Brownlee, R. T. C. \& Chiu, F. C. K. Facile synthesis of protected dipeptide acids containing C-terminal $\alpha, \alpha$-dialkyl amino acids. Tetrahedron Lett. 32, 3407-3408 (1991).

25 Seok Choi, J., Kang, H., Jeong, N. \& Han, H. Orthogonality and compatibility between Tsc and Fmoc amino-protecting groups. Tetrahedron 61, 2493-2503 (2005).

26 Niestroj, A. J. et al. Inhibition of mammalian legumain by Michael acceptors and AzaAsn-halomethylketones. Biol. Chem. 383, 1205-1214 (2005).

27 Flotow, H., Leong, C.-Y \& Buss, A. D. Development of a plasmepsin II fluorescence polarization assay suitable for high throughput antimalarial drug discovery. J. Biomol. Screen. 7, 367-371 (2002).

28 Ovenden, S. P. B et al. Spermine alkaloids from Albizia adinocephala with activity against Plasmodium falciparum plasmepsin II. Phytochemistry 60, 175-177 (2002)

29 Yang, L. K. et al. Pyrrole carboxamidine tryptase inhibitors from Leptonychia pubescens. Planta Med. 71, 1071-1072 (2005).

Supplementary Information accompanies the paper on The Journal of Antibiotics website (http://www.nature.com/ja) 